\title{
Moças graciosas e rapazes disciplinados: papeis sociais de gênero e interseções com a história das rivalidades entre as escolas estaduais em Belém-Pa nas imagens do jornal "O Liberal" (1971-1980)
}

\author{
Graceful girls and disciplined boys: gender social roles and intersections with the history of \\ rivalries between state schools in Belem-Pa in the images of the journal "The Liberal" (1971-1980) \\ Niñas elegantes y niños disciplinados: roles sociales de género e intersecciones con la historia de \\ rivalidades entre escuelas estatales en Belém-Pa en las imágenes de la revista "El Liberal" (1971-
}

\section{Resumo}

O presente trabalho possui como objetivo principal investigar questões de gênero no âmbito da história das rivalidades entre as escolas estaduais em Belém-Pa, que atualmente se configura como problema notadamente de violência escolar. Ante tal iniciativa, aponta-se como questão norteadora do estudo, saber: Quais os sentidos e imagens produzidos nas matérias de jornal da década de 1970, no âmbito da midiatização das festas cívicas escolares em Belém-Pa, acerca de jovens mulheres estudantes e sua relação com o contexto social do período histórico em análise? A partir de uma pesquisa de natureza documental, cujo corpus constitui-se de dezoito (18) matérias midiáticas impressas da década de1970. Cuja análise deu-se à luz da análise de sentido conforme a teoria bakhtiniana. Observouse que havia papeis sociais diferentes para jovens moças e rapazes, o que demonstra um projeto de formação socioeducacional calcados em questões de gênero e desigualdades. Para as jovens do sexo feminino a formação para o casamento e entretenimento social; e para os jovens meninos um ethos masculizante, virilidade, ser racional, inteligente e formação para postos de comando e liderança. Pelo que se espera contribuir com subsídios materiais e históricos para melhor compreender a construção da imagem da mulher - jovem estudante - a partir da tessitura midiática e sua relação com o contexto socioeducacional experimentado durante o período ditatorial, e assim reconduzir à própria história da educação no Estado do Pará.

Palavras-chave: História da educação na Amazônia; Festas cívicas; Gênero.

\begin{abstract}
The main objective of the present work is to investigate gender issues in the context of the history of rivalries between state schools in Belem-Pa, which is currently configured as a problem notably of school violence. In view of this initiative, the guiding question of the study is to know: What are the meanings and images produced in newspaper articles from the 1970s, within the scope of the mediatization of school civic parties in Belem-Pa, about young female students and their relationship with the social context of the historical period under analysis? Based on documental research, whose corpus consists of eighteen (18) printed media materials from the 1970s. Whose analysis was conducted in the light of the analysis of meaning according to the Bakhtinian theory. It was observed that there were different social roles for young girls and boys, which demonstrates a socio-educational training project based on gender issues and inequalities. For young females, training for marriage and social entertainment; and for young boys a masculine ethos, virility, being rational, intelligent, and training for positions of command and leadership. Therefore, it is expected to contribute with material and historical subsidies to better understand the construction of the image of women - young students - from the media fabric and its relationship with the socio-educational context experienced during the dictatorial period, and thus lead back to the history of education in the State of Pará.
\end{abstract}

Keywords: History of education in the Amazon; Civic parties; Genre. 


\begin{abstract}
Resumen
El objetivo principal del presente trabajo es investigar las cuestiones de género en el contexto de la historia de rivalidades entre las escuelas públicas de Belém-Pa, que actualmente se configura como un problema notablemente de violencia escolar. Ante esta iniciativa, la pregunta orientadora del estudio es saber: ¿Cuáles son los significados e imágenes producidas en los artículos periodísticos de la década de 1970, en el ámbito de la mediatización de las fiestas cívicas escolares en Belém-Pa, sobre las jóvenes estudiantes y su relación con el contexto social del período histórico analizado? Basado en una investigación documental, cuyo corpus consta de dieciocho (18) materiales impresos de los años setenta. Cuyo análisis se llevó a cabo a la luz del análisis de significado según la teoría bakhtiniana. Se observó que existían diferentes roles sociales para los niños, lo que demuestra un proyecto de formación socioeducativa basado en la problemática y las desigualdades de género. Para las mujeres jóvenes, formación para el matrimonio y entretenimiento social; y para los jóvenes un ethos masculino, virilidad, racionalidad, inteligencia y preparación para puestos de mando y liderazgo. Por tanto, se espera contribuir con subsidios materiales e históricos para comprender mejor la construcción de la imagen de las mujeres - jóvenes estudiantes - desde el tejido mediático y su relación con el contexto socioeducativo vivido durante el período dictatorial, y así remontar a la historia de la educación en el estado de Pará.
\end{abstract}

Palabras clave: Historia de la educación en la Amazonía; Fiestas cívicas; Género.

\title{
1. Introdução
}

Ao estudarmos o engendramento histórico das rivalidades escolares em Belém-Pa, a partir de ritualizações e regimes simbólicos constituídos nas programações da Semana da Pátria, pela qual se propunha a validação de certos valores sociais, tais como: patriotismo, disciplina militarizada. Observamos que os papeis sociais atribuídos a jovens rapazes e moças nas matérias do jornal "O Liberal” na década de 1970, diferiam em princípio e objetivo. E, que em boa medida, essa construção social de gênero possui interseções com os episódios de rivalidade entre as escolas, por um ethos guerreiro associada a determinadas manifestações de masculinidade proposta pela dinâmica do evento; que não deixa de resvalar a educação da jovem mulher, mas que é atenuada pelo papel da graciosidade, beleza e cuidado familiar, e em suma de sua objetificação.

Vidal (2007) traz-nos contribuições importantes para visualizarmos o cenário de produções na interseção entre gênero e história da educação, uma vez que ressalta os temas e preocupações de pesquisa mais avultadas e de outra forma, aqueles temas que ficam relegados e ou pouco desenvolvidos. Importante ressaltar de pronto que esses estudos de gênero no área da História da Educação continuam pouco expressivos em relação a outros eixos de estudo, mas que tem demonstrado um crescimento no acúmulo histórico, o que segundo a autora supracitada vem salientando cada vez mais a importância da área.

Segundo Vidal (2007), na década de 1990 o principal interesse era sobre as relações de gênero, centrado na educação da mulher e com pouco diálogo epistemológico entre os dois campos Estudos de Gênero e Educação. Após dez anos, as conclusões ainda apontavam para o caráter preliminar das pesquisas que interseccionavam gênero e educação, mas com sensível aumento no interesse por essas discussões no domínio da História da Educação, período em que também se percebeu uma maior variedade de temáticas - saúde, direitos, violência etc. - ainda que limitadas ao campo da vida adulta.

Em 2005 há três levantamentos realizados com o intuito de situar o interesse pelo tema das relações de gênero na interseção com a Educação e a História da Educação. Araújo; Sá e Madureira; Bastos, Bencostta e Cunha, corroboram com o avanço da diversidade de temáticas, uma maior representatividade em eventos de História da Educação, ainda que os percentuais fossem baixos em relação a outros campos de abordagem; para além do próprio trabalho de Vidal, et. al. publicado em 2005 que percebeu um percentual de trabalhos que interseccionavam etnia, raça e gênero (Vidal, 2007).

De maneira geral, segundo Vidal (2007) há ainda poucos estudos ocupados da interseção entre relações de gênero e história da educação, ainda que o interesse seja crescente. E, dessa forma a autora aponta os temas mais difundidos e os que ela acredita ainda configurarem-se como limites a serem excedidos. Sobre os temas de maior interesse versus lacunas: a) na relação trabalho e mulher sobrepõe-se à docência em detrimento de outras atividades laborais que foram realizadas por mulheres; b) sobre a educação feminina a prevalência seria pelas que foram realizadas em instituições formais e principalmente religiosas, a despeito de iniciativas populares; c) a centralidade na figura da mulher e remissão à figura masculina; d) quanto 
aos aspectos geracionais, há grande interesse pela mulher adulta, a juventude e a terceira idade mostram-se praticamente invisíveis. A criança e a infância que ainda representam um pequeno percentual.

Vidal (2007) também nos convida a interdisciplinarizar mais, sobretudo com a Sociologia e os estudos de gênero. E, dentre tantas outras lacunas ainda esmiuçadas pela autora, as quais tentamos parcamente condensar aqui, ela se refere a uma preocupação sobre o fato de que "[...] estudos sobre gênero parecem associar diretamente a categoria ao universo feminino, tendo dificuldade em abordar o masculino [...]", tanto quanto "[...] a violência escolar associada a manifestações de masculinidade hegemônica [...]" (Vidal, 2007, p. 33).

Dessa forma que problematizamos os papeis sociais de jovens estudantes - rapazes e moças - representados nas imagens de O Liberal na década de 1970. Por considerarmos que os rituais socioeducacionais estabelecidos na Semana da Pátria nesse período, que é um período ditatorial, concorrem para a conformação de um ethos guerreiro, que educa o jovem rapaz sob um modelo de masculinidade pautado em princípios militarizados da disciplina, vigor físico e exercício do poder. E, que de outra forma objetificava a jovem mulher como corpo sexualizado, servil ao homem forte, cuidadora da família, e professora que cuidaria da prospecção do homem de sucesso.

Uma iniciativa que se justifica tanto em sua relevância acadêmico-social porque possibilita compreender dinâmicas próprias do contexto educacional belenense, e da constituição da juventude enquanto categoria histórica, que uma vez negligenciadas, tornam naturalizadas as desigualdades de gênero.

Apontamos ainda, a emergência de trabalhos que discutam as singularidades culturais e educacionais amazônidas em suas manifestações discursivo-sociais, de maneira a se fazerem conhecer não só os processos de construção sobre certos fenômenos sociais, como as questões de gênero, mas também para inserir a região amazônica, de forma mais contundente no contexto maior das iniciativas de produção de conhecimento, nesse âmbito.

Assim que se toma como propósito primordial desse estudo investigar e nuclear os sentidos e imagens produzidos sobre jovens estudantes de ambos os sexos, nas matérias de jornal de "O Liberal" na década de 1970, no âmbito da midiatização das festas cívicas escolares em Belém-Pa, e sua relação com o engendramento das rivalidades entre as escolas.

\section{Metodologia e Apresentação dos Dados}

O estudo caracteriza-se como pesquisa de cunho qualitativo e documental, conforme nos orienta Chizzotti (2003); SáSilva, Almeida, e Guindani (2009); Pádua (2019), já que, os dados foram levantados no arquivo de jornais da Biblioteca Pública Arthur Vianna, no qual foram priorizadas matérias impressas do jornal "O Liberal" da década de 1970 que relatavam os acontecimentos anuais das festas cívicas da "Semana da Pátria", aonde algumas escolas estaduais da região de Belém participavam dos desfiles, disputas de canto orfeônico e os jogos estudantis.

A opção por esse veículo em particular (O Liberal), se deu em virtude de este possuir uma longa história de participação nesse campo discursivo-jornalístico na cidade de Belém, desde 1946, segundo Luft (2015); e, o período em análise se justifica pelos indícios de noticiabilidade dos episódios de rivalidade, de modo a se poder perceber a construção de sentido no percurso histórico da década de 1970.

Tomamos os jornais como uma fonte documental, justamente por nos proporcionarem informações, indicações e esclarecimentos em favorecimento das questões por nós levantadas, servindo para elucidá-las em determinadas circunstâncias e como prova para outras, de acordo com os interesses dessa pesquisa, a maneira de compreensão de Sá-Silva et. al (2009), sobre essa maneira de caracterizar um documento.

A partir desse levantamento, inventariamos as matérias, conforme as seguintes informações: ano, título da matéria, resumo que apresenta em linhas gerais do que a matéria aborda, os signos reiteráveis, e os sentidos próprios da tessitura jornalística. Por considerar o inventário como uma metodologia de organização e tratamento de dados documentais, pelo qual 
nos será proporcionado selecionar as matérias mais relevantes ao alcance de nossos objetivos, assim como aponta Felgueiras (2011), ao articular informações que se veem dispersas nas narrativas midiáticas, e reorganizá-las conforme temas recorrentes, o que favorece a percepção da constituição de sentidos, conforme nos orienta (Prado \& Morais, 2011). O referido Inventário se observa abaixo, no Quadro 1, onde apresentamos síntese das matérias de jornais analisadas.

Quadro 1. Inventário das matérias do jornal O Liberal de 1971 a 1980.

\begin{tabular}{|c|c|c|c|c|c|}
\hline Ano & Data & Título & Resumo & Signos reiteráveis & Sentidos \\
\hline 1971 & $01 / 09$ & $\begin{array}{l}\text { Festa da independência abriu } \\
\text { com fôgo simbólico }\end{array}$ & $\begin{array}{l}\text { Abertura da semana da } \\
\text { pátria com cerimônia } \\
\text { para acender uma pira } \\
\text { cívica }\end{array}$ & $\begin{array}{l}\text { Professora feliz que cita poetas tem } \\
\text { espaço de fala jovem estudante } \\
\text { corpo da mulher estudante à mostra } \\
\text { "Em nome da mulher paraense a } \\
\text { professora [...] salientou" }\end{array}$ & $\begin{array}{l}\text { Vida pública } \\
\text { possível/Atuação } \\
\text { profissional possível } \\
\text { mulher paraense } \\
\text { respeitável }\end{array}$ \\
\hline 1971 & $02 / 09$ & $\begin{array}{l}\text { Manhã de sol na festa dos } \\
\text { JOPAGICO } \\
\text { Beleza e colorido na festa } \\
\text { inicial dos XVII JOPAGICO } \\
\text { (Subtítulo) }\end{array}$ & $\begin{array}{l}\text { Abertura do } \\
\text { JOPAGICO (jogos } \\
\text { paraenses ginásio- } \\
\text { colegiais) }\end{array}$ & $\begin{array}{l}\text { Moças - Garbosidade, beleza, } \\
\text { atletas/ginástica, saias curtas } \\
\text { presença marcante colorido } \\
\text { graça, beleza e muito colorido } \\
\text { Rapazes - destaque ao acender a pira } \\
\text { olímpica }\end{array}$ & $\begin{array}{l}\text { Ambos aparecem sob a } \\
\text { alcunha de "atletas" } \\
\text { mas, para as meninas o } \\
\text { destaque é a ginástica. } \\
\text { E, imagens de } \\
\text { apresentações com } \\
\text { figurinos. }\end{array}$ \\
\hline 1971 & 06/09 & $\begin{array}{l}\text { Escolares dão adeus ao desfile } \\
\text { na praça } \\
\text { Desfile militar começa às } 9 \\
\text { horas com pracinhas } \\
\text { (subtítulo) }\end{array}$ & $\begin{array}{l}\text { Preparação dos } \\
\text { militares em sua rotina } \\
\text { para o desfile. } \\
\text { E, a mudança de local } \\
\text { de realização do } \\
\text { desfile. }\end{array}$ & $\begin{array}{l}\text { Exibição de canto. } \\
\text { Homenagem/professora grande } \\
\text { mestra } \\
\text { "Homenagem à professora [...] que se } \\
\text { encontrava acamada aspas" }\end{array}$ & $\begin{array}{l}\text { reconhecimento do } \\
\text { público à grande } \\
\text { mestra } \\
\text { Atuação profissional } \\
\text { possivel } \\
\text { Mulher paraense } \\
\text { respeitável } \\
\text { Fragilidade Feminina }\end{array}$ \\
\hline 1971 & 06/09 & $\begin{array}{l}\text { Juventude: confiança no brasil } \\
\text { de amanhã }\end{array}$ & $\begin{array}{l}\text { Repercussão do desfile } \\
\text { escolar na praça }\end{array}$ & $\begin{array}{l}\text { Moças - Mocidade garbosa } \\
\text { Mocinha } \\
\text { Espetáculo coreográfico } \\
\text { Rapazes - "Os homens que dirigirão } \\
\text { o Pará de amanhã, passam garbosos e } \\
\text { disciplinados, juventude que se } \\
\text { aprimora nos conhecimentos para } \\
\text { engrandecer a sua terra" }\end{array}$ & 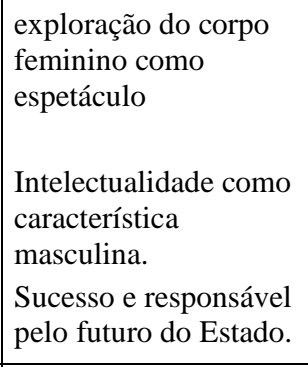 \\
\hline 1972 & $05 / 09$ & $\begin{array}{l}17 \text { mil jovens no desfile do } \\
\text { dia da raça em Belém } \\
\text { (CAPA) } \\
\text { Semana da pátria } \\
17 \text { mil estudantes desfilam } \\
\text { comemorando o dia da raça }\end{array}$ & $\begin{array}{l}\text { Chamada de capa para } \\
\text { o desfile } \\
\text { Desfile do dia da raça. } \\
\text { Sesquicentenário da } \\
\text { independência }\end{array}$ & $\begin{array}{l}\text { Professoranda } \\
\text { Beleza } \\
\text { emoção "as jovens foram o destaque } \\
\text { do desfile de 1972" "garbo e civismo } \\
\text { de suas alunas. "a graça e a beleza da } \\
\text { mulher paraense no desfile" (legenda } \\
\text { da imagem de meninas quase crianças } \\
\text { no desfile). "o moderno apresentou } \\
\text { belíssimas garotas" } \\
\text { "Durante a vários anos, a nossa } \\
\text { participação no defino desfile escolar, } \\
\text { não ultrapassa os limites de } \\
\text { burburinho dos preparativos } \\
\text { convencionais [...]" - fala de uma das } \\
\text { alunas do colégio IEP. } \\
\text { "[...] a expectativa do próprio } \\
\text { momento de nos exibirmos [...]". }\end{array}$ & $\begin{array}{l}\text { Fragilidade feminina, } \\
\text { marcada nos discursos } \\
\text { de emoção referentes } \\
\text { às mulheres } \\
\text { (professora } \\
\text { emocionada, } \\
\text { professoranda). } \\
\text { As próprias estudantes } \\
\text { expressam esses papeis } \\
\text { de "exibição" e } \\
\text { espetáculo pelos trajes } \\
\text { que utilizavam. E, da } \\
\text { pouca importância que } \\
\text { atribui à participação } \\
\text { feminina nos desfiles. }\end{array}$ \\
\hline
\end{tabular}




\begin{tabular}{|c|c|c|c|c|c|}
\hline 1974 & $05 / 09$ & $\begin{array}{l}\text { O canto de cinco mil } \\
\text { estudantes }\end{array}$ & $\begin{array}{l}\text { Festival de canto } \\
\text { orfeônico }\end{array}$ & $\begin{array}{l}\text { "no ritmo e obedecimento" } \\
\text { empolgada } \\
\text { Trajes típicos e vistosos. Empolgou a } \\
\text { multidão. "beleza de apresentação dos } \\
\text { colégios". Num tremendo frenesi. } \\
\text { Graça e beleza nos movimentos das } \\
\text { lindas jovens. }\end{array}$ & $\begin{array}{l}\text { Imagem sensualizada } \\
\text { trajes carnavalescos } \\
\text { diminutos. }\end{array}$ \\
\hline 1974 & $06 / 09$ & $\begin{array}{l}\text { Mais de } 15 \text { mil escolares } \\
\text { desfilaram no dia da raça } \\
\text { (p.15). }\end{array}$ & $\begin{array}{l}\text { Desfile do dia da raça. } \\
\text { Desfile estudantil }\end{array}$ & $\begin{array}{l}\text { "o vigor físico" abaixo da imagem de } \\
\text { estudantes de collant e minissaias. E } \\
\text { "associou-se à técnica do } \\
\text { treinamento" abaixo da imagem de } \\
\text { estudantes de calça tocando } \\
\text { instrumentos }\end{array}$ & $\begin{array}{l}\text { Diferença na exposição } \\
\text { do corpo a partir das } \\
\text { indumentárias. } \\
\text { Superexploração do } \\
\text { corpo feminino. } \\
\text { Relação vigor físico } \\
\text { versus técnica com o } \\
\text { corpo coberto. }\end{array}$ \\
\hline 1974 & 06/09 & $\begin{array}{l}\text { Povo aplaudiu juventude } \\
\text { (p.16). }\end{array}$ & $\begin{array}{l}\text { Repercussão desfile } \\
\text { escolar }\end{array}$ & $\begin{array}{l}\text { Charme e civismo das jovens } \\
\text { escolares. } \\
\text { Desmaios de jovens mulheres }\end{array}$ & $\begin{array}{l}\text { Exploração da imagem } \\
\text { da mulher como } \\
\text { espetáculo/entretenime } \\
\text { nto. } \\
\text { Fragilidade feminina }\end{array}$ \\
\hline 1975 & $06 / 09$ & $\begin{array}{l}\text { No desfile da juventude, sons, } \\
\text { ritmos e cores }\end{array}$ & $\begin{array}{l}\text { Os pormenores do } \\
\text { desfile estudantil. }\end{array}$ & $\begin{array}{l}\text { "de calças compridas ou minissaias } \\
\text { revelando grandes sons..." } \\
\text { As estudantes são o foco do discurso } \\
\text { imagético. "Sons, ritmos e cores } \\
\text { referem-se à participação feminina. }\end{array}$ & $\begin{array}{l}\text { Diferença na exposição } \\
\text { do corpo a partir das } \\
\text { indumentárias. } \\
\text { Superexploração do } \\
\text { corpo feminino. } \\
\text { Mulher como } \\
\text { entretenimento. }\end{array}$ \\
\hline 1976 & 04/09 & $\begin{array}{l}\text { O toque certo para o passo } \\
\text { certíssimo }\end{array}$ & $\begin{array}{l}\text { Cont. Da matéria } \\
\text { principal }\end{array}$ & $\begin{array}{l}\text { Elegância e juventude. Toque de } \\
\text { beleza que não poderia faltar. } \\
\text { Organização, imponência e } \\
\text { juventude. "as mulheres superaram } \\
\text { numericamente os homens no desfile, } \\
\text { por darem os colégios prioridade às } \\
\text { alunas em seus pelotões de ginástica e } \\
\text { educação física, o que contribuiu para } \\
\text { a beleza do espetáculo". Na presença } \\
\text { feminina, o toque de graça e beleza. } \\
\text { Ousadamente bandas só de mulheres. } \\
\text { "... Sozinha, um toque muito } \\
\text { particular ao desfile" }\end{array}$ & $\begin{array}{l}\text { Binarismos de gênero. } \\
\text { Incômodo com o maior } \\
\text { número de alunas } \\
\text { mulheres. } \\
\text { Atividades físicas } \\
\text { distintas por gênero: } \\
\text { alunas (ginástica); } \\
\text { alunos (esportes). }\end{array}$ \\
\hline 1977 & $02 / 09$ & $\begin{array}{l}\text { Festa dos estudantes marca } \\
\text { início da semana da pátria }\end{array}$ & $\begin{array}{l}\text { Trata das } \\
\text { apresentações da } \\
\text { abertura da semana e } \\
\text { pormenores dos } \\
\text { desfiles isolados de } \\
\text { bairro. }\end{array}$ & $\begin{array}{l}\text { "os números de ginástica feminina } \\
\text { moderna foram os mais aplaudidos" }\end{array}$ & $\begin{array}{l}\text { Atividades físicas } \\
\text { distintas por gênero }\end{array}$ \\
\hline 1978 & $05 / 09$ & $\begin{array}{l}\text { Sete mil alunos festejam a } \\
\text { independência }\end{array}$ & $\begin{array}{l}\text { Cobertura do desfile } \\
\text { estudantil principal. } \\
\text { Com destaque para as } \\
\text { bandas marciais. A } \\
\text { ordem de desfile. }\end{array}$ & $\begin{array}{l}\text { "na banda do IEEP homem não toca". } \\
\text { Fato inédito um pelotão masculino no } \\
\text { IEEP. "gerou muita polêmica, } \\
\text { principalmente entre as feministas } \\
\text { radicais..." }\end{array}$ & $\begin{array}{l}\text { Disputa pautada em } \\
\text { diferenças de gênero. }\end{array}$ \\
\hline 1978 & $06 / 09$ & $\begin{array}{l}\text { Durante o desfile, beijo } \\
\text { roubado tumulto e o colégio } \\
\text { do governador }\end{array}$ & $\begin{array}{l}\text { O destaque é para um } \\
\text { beijo roubado dado em } \\
\text { uma estudante e } \\
\text { desmaios. }\end{array}$ & $\begin{array}{l}\text { "socorreu vários estudantes, } \\
\text { principalmente moças que sofreram } \\
\text { desmaios" }\end{array}$ & $\begin{array}{l}\text { Como as mais frágeis. } \\
\text { Fragilidade Feminina. }\end{array}$ \\
\hline 1979 & 03/09 & $\begin{array}{l}\text { Desfiles escolares } \\
\text { movimentam os bairros }\end{array}$ & $\begin{array}{l}\text { Cobertura dos desfiles } \\
\text { nos bairros. Escolas de } \\
1^{\circ} \text { grau (rede estadual e } \\
\text { municipal) e } \\
\text { particulares. }\end{array}$ & $\begin{array}{l}\text { Alunas do Justo Chermont (com } \\
\text { imagem) "colegiais deram um toque } \\
\text { de graça e beleza (com imagens de } \\
\text { alunas) }\end{array}$ & $\begin{array}{l}\text { Imagem de estudantes } \\
\text { mulheres como } \\
\text { entretenimento/adereço } \\
\text { s/decoração da festa. }\end{array}$ \\
\hline
\end{tabular}




\begin{tabular}{|c|c|c|c|c|c|}
\hline 1979 & 06/09 & $\begin{array}{l}\text { As imagens da festa dos } \\
\text { estudantes }\end{array}$ & $\begin{array}{l}\text { Cobertura do desfile } \\
\text { estudantil. Destaque } \\
\text { para o retorno das } \\
\text { torcidas. }\end{array}$ & $\begin{array}{l}\text { "as alunas do IEP, que apresentaram } \\
\text { sua banda própria". } \\
\text { "a banda do instituto veio com força } \\
\text { total, formada unicamente de moças" }\end{array}$ & $\begin{array}{l}\text { Mulheres como } \\
\text { alegorias da festa. } \\
\text { Outros papeis além } \\
\text { desse alegórico, são } \\
\text { postos em suspeição. }\end{array}$ \\
\hline 1980 & $02 / 09$ & $\begin{array}{l}\text { Atletismo por dois mil alunos } \\
\text { abre festas da semana da } \\
\text { pátria }\end{array}$ & $\begin{array}{l}\text { Festividade de abertura } \\
\text { com os jogos } \\
\text { estudantis. }\end{array}$ & Representação masculina de atleta & $\begin{array}{l}\text { Viril, esportes de } \\
\text { competição }\end{array}$ \\
\hline 1980 & $06 /$ set & $\begin{array}{l}\text { Um carnaval no rastro da } \\
\text { última banda }\end{array}$ & $\begin{array}{l}\text { O encerramento das } \\
\text { festividades da semana } \\
\text { da pátria com o desfile. }\end{array}$ & Carnaval/festa/e o feminino & $\begin{array}{l}\text { Representação da } \\
\text { figura feminina } \\
\text { relacionada ao } \\
\text { carnaval/carnavalesca/ } \\
\text { artística/ espetáculo }\end{array}$ \\
\hline
\end{tabular}

Fonte: Autores.

No decorrer da pesquisa, um dos processos mais enriquecedores para realização das análises e que possibilitou maior aproximação ao objeto em estudo foi a elaboração do inventário acima, demonstrado no Quadro 1. Dentre o número de duzentos e quarenta e nove (249) matérias impressas do jornal "O Liberal" da década de 1970 levantadas acerca da festa cívica escolar realizada na semana da pátria e sua relação com a criação e desenvolvimento da rivalidade ente escolas, observamos que dezoito (18) apresentaram abordagens explícitas de questões de gênero. Quatro (4) matérias do ano de 1971; duas (2) matérias de 1972; nenhuma matéria no ano de 1973; três (3) matérias de 1974; uma (1) matéria em 1975; uma (1) matéria em 1976; uma (1) matéria no ano de 1977; duas (2) matérias encontradas no ano de 1978; duas matérias (2) no ano de 1979; e duas (2) matérias no ano de 1980.

Consonante ao inventariado, observa-se que durante toda a semana de comemoração fora destinado ao menos duas páginas do jornal para cada dia de matérias publicadas em alusão aos desfiles escolares; militares; às disputas de canto orfeônico e aos jogos estudantis, além de identificarmos a presença de muitas imagens relacionadas a estes. Dentro do contexto imagético e escrito nas publicações é notório a forte exaltação e destaque às vestimentas e atribuições dos corpos femininos, desde o primeiro dia de programações da semana as jovens estudantes são expostas e têm seus corpos hiper sexualizados desde a cerimônia de abertura até a culminância no encerramento com os desfiles. Nas imagens exibidas nos jornais da década em estudos, as jovens sempre aparecem em destaque, estando sempre com saias e shorts curtos, ou roupas extremamente justas ao corpo, além de serem retratadas apenas por sua beleza, graça e formosura, enquanto aos jovens homens são destinados valores e atribuições de garra e prospecção de futuro.

Nossas incursões teórico-metodológicas reafirmam nossa análise a partir da teoria/análise dialógica do discurso bakhtiniano, ao subsidiar o ressalte dos sentidos e imagens produzidos pelas matérias de jornal sobre as jovens estudantes, ao considerar que tais sentidos são tecidos nas relações que se estabelecem entre os discursos veiculados nessa mídia e a propósito do contexto social sob o qual se manifesta. Disto depreende-se, um processo de significação, que mostramos na Figura 1.

A Figura 1 demonstra um fluxograma, a partir do qual, podemos perceber o discurso enquanto linguagem em movimento, e constituído por contextos discursivos que articulam significados (signos), e temas - signos ideológicos e sentidos assumidos na enunciação concreta, segundo Brait (2008); Bakhtin (2014). Nesse processo e pela maneira como conflui a significação é possível apontar uma apreciação social inscrita no discurso (Dahlet, 2005; Brait, 2010), um posicionamento acerca de uma questão social, em nosso caso sobre as questões gênero. 
Figura 1. Matriz Analítico-Compreensiva do Corpus de Pesquisa.

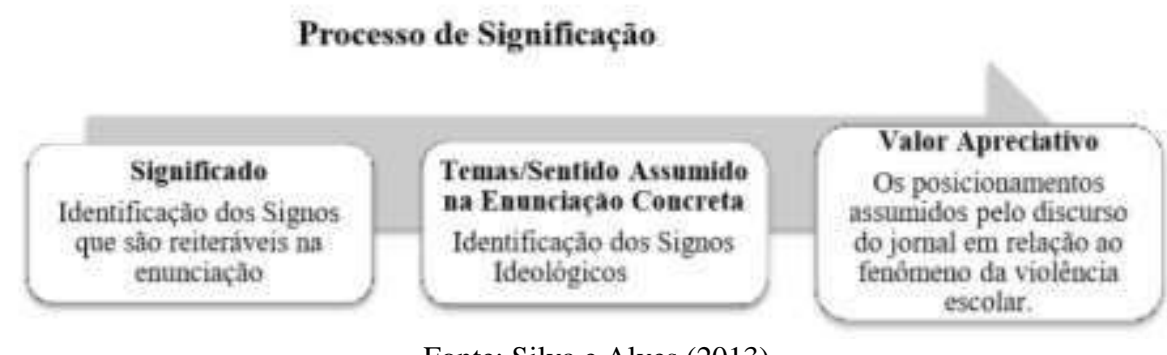

Fonte: Silva e Alves (2013).

O processo de significação se caracteriza pela operação de três processos: o da percepção de que, todo sistema linguístico guarda palavras/signos mais ou menos estáveis em sua compreensão. Assim, quando ouvimos a palavra cadeira, ou mesa todos tem uma ideia, uma imagem comum dos objetos aos quais os termos se referem. Esses são o que Bakhtin (2014) chama de "significado". Em uma análise discursiva com base nos pressupostos bakhtinianos, vamos percebendo que, há certos signos que se repetem na enunciação, e são recorrentemente mobilizados.

Tais signos reiteráveis, ainda que com seus significados mais ou menos estáveis, assumem sempre sentidos que são próprios da enunciação concreta, conforme explica Brait (2008) e Dahlet (2005); já que, os contextos, os sujeitos enunciantes e a organização dos termos em uma oração implicam diretamente na semântica do texto. A observãncia desse processo de transmutação de significado a sentido na enunciação concreta, possibilita perceber as intenções e interesses dos sujeitos enunciantes, os posicionamentos sociais assumidos. Nesse caso, não só dos readatores das matérias, mas de um posicionamento social do jornal, e da propria sociedade daquela época, de maneira geral, porque há midiatização.

Vários estudiosos dos processos comunicacionais nos ensinam que, a produção jornalística está sempre em diálogo com a sociedade, e se sustenta, justamente, porque em boa medida representam os valores e interpretação de mundo de boa parte de seus leitores. O jornal escreve para um público dado e não venderia caso se colocasse sempre em antagonismo com esse (Fausto Neto, 2006; 2008; Gomes, 2008; Pares, 2008; Bortoli, 2009; Barros, 2012; Hjarvard, 2012).

Aliadas aos teóricos da análise do discurso, as teorias de gênero nos permitirão ter uma abordagem ampla para analisar a construção midiática sobre a mulher jovem estudante e como esse fenômeno reflete as relações de poder existentes na época.

Dessa forma, os estudos de gênero se configuram como parte essencial dessa pesquisa. Uma vez que visa investigar a construção de uma feminilidade em que mulheres jovens deveriam ser socializadas na época. Os estudos de gênero também servem para demonstrar que as construções de imagens da mulher - principalmente, da mulher jovem - tem raízes também na colonialidade e na necessidade de controle desses corpos para manter uma dominação, segundo (Gomes, 2018).

De acordo com Gomes (2018) os estudos de gênero - em especial, sobre as mais diversas formas de violência de gênero - se tornam campo teórico-metodológico na década de 80 com ajuda dos movimentos sociais. Esse campo é bastante necessário para evitar uma naturalização das construções sociais em cima do ser mulher. Necessário, principalmente, para ter a compreensão de que o local de subordinação do gênero feminino se dá por uma construção social.

\section{Resultados e Discussão}

Segundo Paulino e Pereira (2006), Saviani (2008), Furlan (2011) e Lobato (2018), o regime ditatorial ainda vigente no Brasil na década de 1970, traçava e impulsionava o plano de "progresso" para o país, pautado na reconstrução da ordem social nas esferas econômica, política e cultural, a qual chamavam de "modernização conservadora" da sociedade. Os governos militares centravam-se na construção de um hipotético ideário de democracia, centrados na ideia de que o regime era uma obra 
de cultura, que buscava alinhar as instituições e as pessoas a um suposto modelo ideário de valores democráticos que incontestavelmente legitimava o regime em vigor. Esse período foi marcado fortemente pela criação e divulgação do sistema de valores moldados pelas instituições militares, valores que se pautavam no enaltecimento do patriotismo, anticomunismo, disciplina militarizada, conservadorismo, forte apego aos valores tradicionais patriarcais da família, e outros referentes à cooperação e não conflito com o Estado, além da forte repressão aos seus opositores.

Durante todo esse período é possível evidenciarmos a forte aclamação ao modelo conservador patriarcal de família, moldado em espelhos de famílias perfeitas, onde os homens são os provedores, chefes da família, e responsáveis em manter as "rédeas" do lar, considerados como pilar principal, enquanto as mulheres eram responsáveis pela manutenção e tarefas do lar, o cuidado dos filhos, dos estudos deles, sendo assim mais restritas aos afazeres que permeiam os cuidados da casa e das crianças, com base nos estudos de Cecarelli (2007) e Goldani (2005).

A imprensa, segundo Napolitano (2014), foi fortemente perseguida e censurada pelos governos durante a ditadura, mas seus segmentos mais liberais tinham uma certa ambiguidade. Nesse sentido, foram os jornais, um dos principais meios de propagação usados para transmitir os espelhos de modelo de família e os papeis de homens e mulheres ideais de uma sociedade, através desses recursos midiáticos os governos do regime impulsionavam e internalizavam seus ideários com grande alcance. Ademais, algumas instituições também eram tidas como meio de internalização desses valores e ideais, a escola era uma das principais, sendo importante espaço para difusão de conhecimentos e objetivos que uma sociedade almeja para formação dos jovens do futuro, estes seriam responsáveis pela manutenção e perpetuação do plano de progresso e ideário de sociedade traçado pelo regime ditatorial.

Durante esse período a formação advinha das escolas normais que preparavam e formavam as mulheres para o magistério, intensificando fortemente sua feminização, pautada sobre a ideia de que às mulheres foi destinado a vocação para o ensino, pelo tato com as crianças (Warde \& Rocha, 2018), ideias enraizadas no seio da sociedade que se fundamentam a partir do sistema patriarcal a qual fomos impostos, reproduzidos no modelo de família conservador, estes amplamente propagados e internalizados durante a ditadura militar.

Aos jovens homens fora dado o papel de destaque fundamental para impulsionar tais valores impostos, eram eles que seriam o futuro da nação, responsáveis pelo seguimento do "plano de progresso" traçado e os próximos mantenedores do projeto de sociedade ideal, enquanto às jovens mulheres foram designadas ao papel de educadoras e formadoras desses "futuros homens".

\subsection{Sentidos e imagens atribuídos às meninas: mães de família versus objeto sexualizado = objetificação da mulher}

Vamos apresentar como que as imagens das jovens estudantes se viam representadas no discurso do jornal O Liberal na década de 1970. Observamos, no decorrer do processo de estudo e pesquisa acerca das festas escolares cívicas da Semana da Pátria, que havia uma distinção flagrante da forma como se apresentavam as figuras de jovens moças da dos rapazes. Vimos a juventude ser representada por um recorte de gênero, apontando papéis sociais respectivos para os quais, o projeto de formação e educacional desenvolvido por meio dessas festividades, convergiam.

Alguns signos e ou palavras são muito recorrentes, como é possível observar no inventário das matérias (Quadro 1). Beleza, Graça, Espetáculo, a ginástica, e a formação em magistério (professorandas, normalistas) aparecem recorrentemente. Tais expressões possuem um significado mais ou menos consensual em nossa língua, poder-se-ia dizer de um significado dicionarizado que é mais estável. De outra forma, considerando-se a forma como o discurso é disposto pelo referido jornal, inclusive no diálogo entre discurso escrito e imagético, vamos percebendo que essas palavras reiteráveis vão constituindo sentidos outros para os quais não foram objeto de origem.

A imagem um representa bastante o sentido de utilização da mulher estudante enquanto objeto de entretenimento e 
espetacularização das atividades festivas escolares da Semana da Pátria. Observe que, embora a matéria trate do percurso da tocha olímpica, é a presença da figura feminina em primeiro plano na imagem que mais se destaca inclusive expressando discurso próprio em relação ao discurso escrito uma vez que pouco representa o principal tema da matéria que era na verdade a solenidade de acendimento da tocha olímpica.

É assim que se constrói a partir dos signos de graça, beleza, vigor físico adquirido com ginástica, criam uma representação da jovem estudante a partir de sua feminização e hiperssexualização. O que melhor se observa no discurso imagético que realça o corpo feminino como símbolo, do entretenimento principal dessas festividades. Observe que: "a graça e a beleza da mulher paraense no desfile" tornam as "as jovens [sic] no destaque do desfile de 1972". Os "trajes típicos e vistosos" que empolgavam a multidão. [...] o que contribuiu para a beleza do espetáculo". Um sentido que se vê de forma ainda mais contundente no discurso imagético, como se observa na Figura 2.

Figura 2. Corpo feminino como espetáculo.
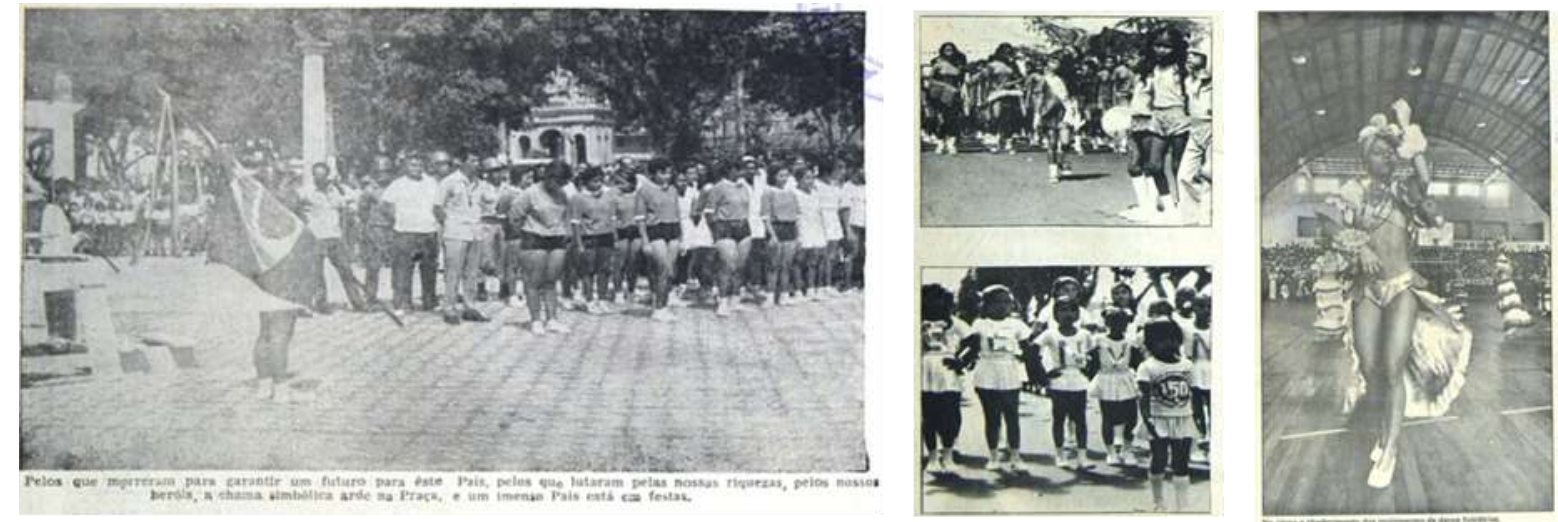

Fonte: Hemeroteca pública Arthur Viana. Jornal O Liberal (01/09/71, 05/09/1972, 05/09/1974 respectivamente).

O corpo feminino se via tão hiperexplorado pelo discurso do jornal em análise, que nem mesmo o corpo infantil escapava a hiper sexualização, como se observa ainda na Figura 2.

Outro sentido presente é o da fragilidade, posto que algumas dessas notícias evidenciam as mulheres como aquelas que passavam mal, ou sentiam-se mal durante os desfiles. Eram eminentemente os desmaios femininos os únicos noticiados. Vê-se em: "socorreu vários estudantes, principalmente moças que sofreram desmaios".

Esse sentido de fragilidade feminina está espraiada em praticamente todo o corpus de pesquisa, mas aparece sobretudo, nos discursos sobre a emoção de mulheres durante o desfile, como por exemplo de professoras homenageadas, e de outras que são destacadas por processos de adoecimento; assim como pelas imagens de desmaios de mulheres durante o desfile, como se pode notar na Figura 3. 
Figura 3. Fragilidade Feminina.

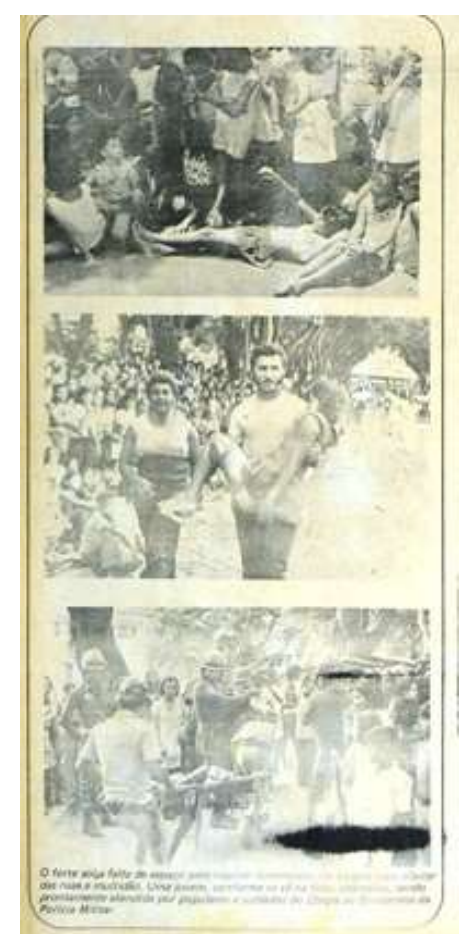

Fonte: Hemeroteca pública Arthur Viana. Jornal O Liberal (06/09/1974)

A Figura 3 retrata a imagem de mulheres ao chão e sendo transportada em maca, ao que o jornal menciona em seu texto escrito, tratar-se de desmaios por conta do sol e alimentação insuficiente anterior a participação no desfile.

E, de outra forma, o sentido de profissionalização/desprofissionalização da figura das estudantes. Já que, embora estivessem se formando em magistério, e fossem àquele tempo normalistas, professorandas etc. Não são destacadas como os rapazes por sua capacidade de liderança, de assumir cargos, de desenvolver o Estado. Ao contrário, ou na direção oposta, posto que todo seu "civismo" está relacionado às suas características físico-corporais, e de sua "capacidade" de entretenimento. Formar-se como professora só contribuía para a formação de uma certa "cultura", erudição, e qualidades maternais, para a educação de crianças, principalmente, os filhos.

\subsection{Sentidos e imagens atribuídos aos meninos: constituição de um ethos de masculinidade}

Diferentemente, para os alunos do sexo masculino o que se vê é a sua representação a partir de categorias tais quais a virilidade, a competitividade, o desenvolvimento do intelecto, e de sua potencial atuação em esferas de liderança, poder e desenvolvimento da sociedade, do estado e da região. no discurso sobre os jovens estudantes não há espaço para emoções, fragilidades, atividade artística ou para a exposição e ou referência aos seus corpos como se os principais atributos. O que Penha (2016, p.2) considera como a "perpetuação de uma de uma masculinidade guerreira", que colaboraria então, para a manutenção de um "modelo normativo de gênero" sob valores que vão sendo "disseminados de geração para geração" na conformação de um projeto de formação socioeducacional que incita a violência, que produz sujeitos violentos.

Em todos os anos de realização das festividades da Semana da Pátria, os esportes tiveram importância significativa e representação reiterada quer seja pelo próprio desenvolvimento dos jogos estudantis durante as festividades da semana, quer seja como tema de apresenta ações nas atividades do cantor orfeônico, ou dos desfiles propriamente ditos.

Vê-se contudo, na Figura 4 que o sentido de atleta, desenvolvimento físico, vigor físico assumiram sentidos diferenciados conforme o gênero. Para os rapazes, a virilidade das atividades competitivas, o esforço, o empenho, as vitórias. 
para as estudantes do sexo feminino a exibição dos corpos, a beleza, a graça e a representação como objeto decorativo, alegórico, festivo, quer dizer, como entretenimento durante os desfiles.

Figura 4. Virilidade e espírito competitivo: ethos de masculinidade versus atletas mulheres
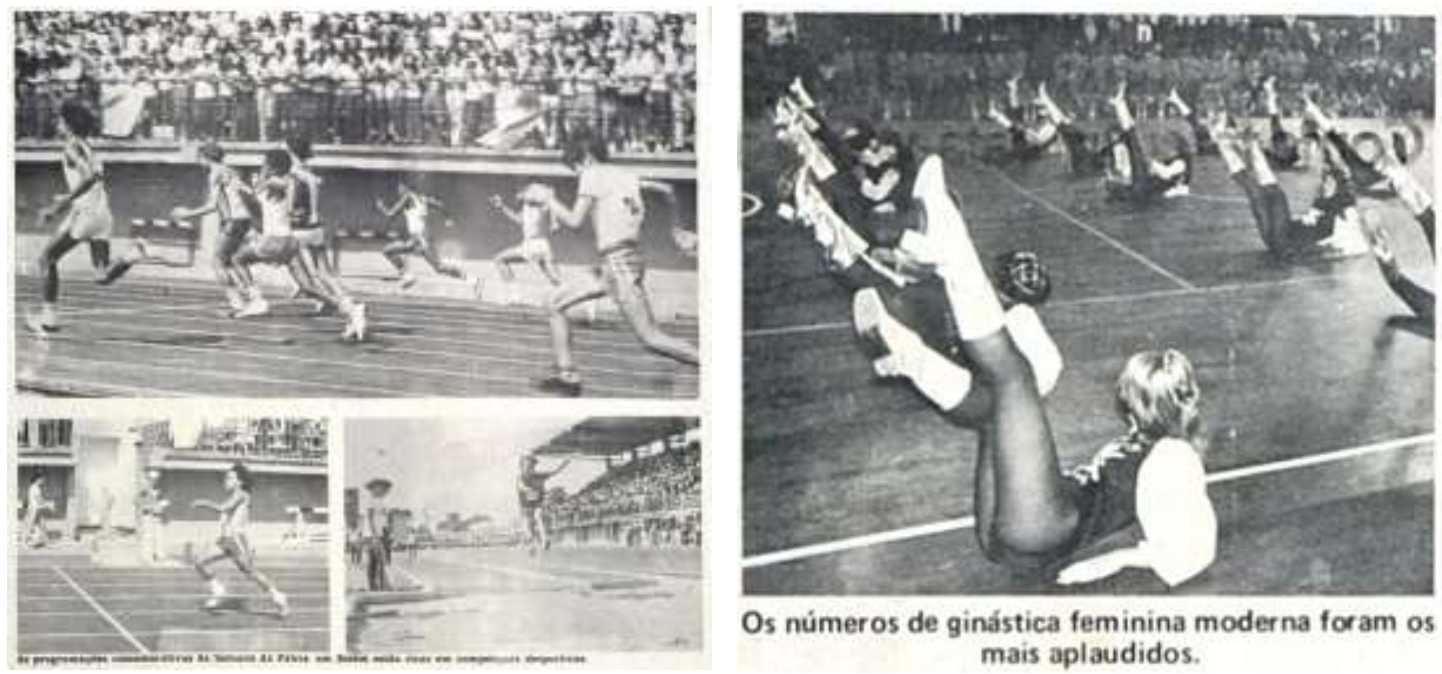

Os números de ginástica feminina moderna foram os mais aplaudidos.

Fonte: Hemeroteca pública Arthur Viana. Jornal O Liberal (02/09/80 e 02/09/77).

Importante ainda ressaltar como esses jovens eram destacados a partir de características como racionalidade, conhecimento, intelectualidade e profissionalismo, uma vez que em sendo considerados os futuros dirigentes do estado, responsáveis pelo progresso da região, e como a esperança de um futuro próspero Dessa forma o sentido de profissional aqui denotado não é somente figurativo, algo de que esse jovem vá aproveitar apenas em foro íntimo particular privado, ao contrário a profissionalização do jovem do sexo masculino servia a esfera pública, há um bem maior, para além do seu círculo familiar. O jovem estudante era possível deixar um legado.

\section{Considerações Finais}

Uma das principais fontes de resultados que obtivemos foi o inventário, onde conseguimos evidenciar como as jovens mulheres estudantes eram vistas naquela época, onde sua imagem era objetificada e sexualizada, pois, as mesmas eram vistas como aquelas que serviriam aos seus maridos, os jovens que eram tratados como o promissor futuro do país, além de serem vistas como mero objeto sexual de serventia aos homens (De Souza, Baldwin, \& Rosa, 2000).

Dentro do contexto imagético e escrito nas publicações foi possível notarmos forte exaltação e destaque às vestimentas e atribuições dos corpos femininos, desde o primeiro dia de programações da semana as jovens estudantes são expostas e têm seus corpos hiper sexualizados desde a cerimônia de abertura até a culminação no encerramento com os desfiles. Nas imagens exibidas nos jornais da década as jovens sempre aparecem em destaque, estando sempre com saias e shorts curtos, ou roupas colantes, além de serem retratadas apenas por sua beleza, graça e formosura, enquanto aos homens é são destinados valores e atribuições de garra e prospecção de futuro.

Mediante este estudo notamos como a mulher, seu corpo e subjetividades são veemente negligenciadas através dos anos, como seu corpo é carregado de objetificação, e a importância do feminismo de luta e resistência para a construção de uma nova imagem e significação do que é ser mulher.

Faz-se urgente discutir as implicações desse imaginário cívico-militar constantemente retroalimentado m nosso percurso histórico de políticas de governo em nosso país, e de suas consequências na formação de valores socioeducacionais 
que ainda hoje vemos animar políticas públicas, modelos de gestão educacional e o próprio comportamento das pessoas. Esperamos contribuir com o avanço das análises entre as áreas da História da Educação e dos estudos de gênero, e que em resposta e prosseguimento a esse texto, e ou em sua contraposição outros venham dialogar com os temas da subjetivação de mulheres ainda na sua infância e juventude, no seio das ações educacionais.

\section{Referências}

Bakhtin, M. (2014). Marxismo e Filosofia da Linguagem (16a ed.). Hucitec.

Barros L., L. M. (2012). Recepção, Mediação e midiatização: conexões entre teorias europeias e latino-americanas. Em Jeder Janotti Junior, Maria Ângela Mattos \& Nilda Jacks (Org.). Mediação e Midiatização. EDUFBA. Compós, 2012.

Bortoli, J. d. (2009). Midiatização e o possível indício de prática social. III Encontro de Pesquisa em Comunicação e Cidadania, 1-10. https://files.cercomp.ufg.br/weby/up/76/o/midiatizacao.pdf.

Brait, B. (2008). Bakhtin: conceitos-chave. Contexto.

Brait, B. (2010). Bakhtin: outros conceitos-chave. Contexto.

Cecarelli, P. R. (2007). Novas Configurações Familiares: mitos e verdades. Jornal de Psicanálise, 89-102. http://pepsic.bvsalud.org/scielo.php?script=sci_ar ttext\&pid=S0103-58352007000100007.

Chizzotti, A. (2003). A pesquisa qualitativa em ciências humanas e sociais: evolução e desafios . Revista Portuguesa de Educação, 221-236. https://www.redalyc.org/pdf/374/37416210.pdf.

Dahlet, P. (2005). Dialogização enunciativa e paisagens do sujeito. Em Bakhtin, dialogismo e construção do sentido (pp. 59-88). Editora da UNICAMP.

De Souza, E., Baldwin, J. R., \& Rosa, F. H. (2000). A construção social dos papéis sexuais femininos. Psicologia: Reflexão \& Crítica, 485-496. https://doi.org/10.1590/S0102-79722000000300016.

Fausto Neto, A. (2006). Midiatização, prática social - prática de sentido. $15^{\circ}$ Encontro Anual da COMPÓS - Associação Nacional dos Programas de PósGraduação em Comunicação, 1-15.

Fausto Neto, A. (2008). Mudanças da Medusa? A enunciação midiatizada e sua incompletude. Em Fausto Neto et. al. Midiatização e processos sociais na América Latina. Paulus.

Felgueiras, M. L. (2011). Herança educativa e museus: Reflexões em torno das práticas de investigação, preservação e divulgação histórica. Rev. bras. hist. educ, 11, 67-92. https://periodicos.uem.br/ojs/index.php/rbhe/article/view/38507.

Furlan, E. (2011). Educação na década de 1970: formação sem informação. Jornada do HISTEDBR. 11. 2013, Anais. Campinas: EdUnicamp. 1-12. http://www.histedbr.fe.unicamp.br.

Gomes, C. D. (2018). Gênero como categoria de análise decolonial. Civitas, 18. https://doi.org/10.15448/1984-7289.2018.1.28209.

Gomes, P. G. (2008). O processo de midiatização da sociedade e sua incidência em certas práticas sociossimbólicas na contemporaneidade. Em Fausto Neto, P. G. Gomes, J. L. Braga, \& J. Ferreira, Midiatização e processos sociais na América Latina (pp. 17-30). Paulus.

Hjarvard, S. (2012). Midiatização: teorizando a mídia como agente de mudança social e cultural. Matrizes, 53-91. https://www.revistas.usp.br/matrizes/article/view/38327.

Lobato, S. (2018). O espetáculo da ordem: paradas estudantis amapaenses em tempos de ditadura (1967-1972). Em M. d. França, S. Lobato, \& V. S. Nery, História da Educação na Amazônia: múltiplos sujeitos e práticas educativas. CRV.

Napolitano, M. (2014). 1964: história do regime militar no Brasil. Contexto.

Pádua, E. M. (2019). Metodologia da pesquisa: abordagem teórico-prática. Papirus Editora.

Pares, A. D. (2008). Comunicação como midiatização: os meios em meio à tecnologia, sociedade, linguagem e vice-versa. Em Questão, $247-259$.

Paulino, A. F., \& Pereira, W. (2006). A educação no estado militar (1964-1985). pp. 1942-1951. http://www.lo.unisal.br/nova/sala2008/sa la2008_2/tex tos/educacao_regime.pdf.

Penha, L. T. (2016). Masculinidade e violência: o ethos guerreiro por uma perspectiva mitológica. Cadernos de Iniciação Científica.. 1-15. https://revistas.direitosbc.br/index.php/CIC/article/view/832/742

Prado, G. d., \& Morais, J. d. (2011). Inventário - organizando os achados de uma pesquisa. EntreVer, 1, 137-154. https://periodicos.ufsc.br/index.php/EntreVer/article/view.

Sá-Silva, J. R., Almeida, C. D., \& Guindani, J. F. (2009). Pesquisa documental: pistas teóricas e metodológicas. Revista Brasileira de História e Ciências Sociais, 1-15. https://periodicos.furg.br/rbhcs/article/view/10351.

Saviani, D. (set./dez. de 2008). O legado educacional do regime militar. Caderno CEDES, 291-312. http://www.cedes.unicamp.br. 
Research, Society and Development, v. 10, n. 12, e430101220671, 2021

(CC BY 4.0) | ISSN 2525-3409 | DOI: http://dx.doi.org/10.33448/rsd-v10i12.20671

Silva, L. S. \& Alves, L. M. (2013). A criminalização da juventude no discurso midiático da violência escolar em Belém-PA. Revista Cadernos de Ciências Sociais da UFRPE, 2. http://www.journals.ufrpe.br/index.php/cadernosdecienciassociais/article/view/351.

Vidal, D. G. (2007). Um olhar sobre os estudos de gênero em História da Educação. Em C. C. Morais, É. A. Portes, \& M. A. Arruda, História da Educação: ensino e pesquisa (pp. 10-38). Autêntica.

Warde, M. J. \& Rocha, M. J. (2018). Feminização do magistério e masculinização do comando educacional: estudos no Teachers College da Universidade de Columbia (1927-1935). Educar em Revista [online], 35-50. https://www.scielo.br/j/er/a/tHm7qYwTNp3ZMDyxMRWKDKw/abstract/?lang=pt\#. 